\title{
PENERAPAN MODEL PEMBELAJARAN INDUKTIF UNTUK MENINGKATKAN AKTIVITAS BELAJAR PKn SISWA DI KELAS VI SD NEGERI NO. 050674 BINGAI
}

\author{
Mas Amah \\ Guru Di SD Negeri No. 050674 Bingai \\ Surel : masamah171@yahoo.com
}

\begin{abstract}
The Application Learning Model Inductive To Improving Learning Activities Lesson In Civic Education Student In Class VI SD Negeri No. 050674 Bingai T.A 2015/2016. This research aims to improve students' learning activities using Inductive learning model in class VI SD Negeri No. 050674 Bingai. These research subjects are 23 students. The study lasted for two cycles can be concluded that 1) Activities of student learning through the implementation of the Inductive learning model is based on observations of the two observers increased from the first cycle to the second cycle. 2) The results of student learning through the implementation of the Inductive learning model increases from the first cycle to the second cycle.
\end{abstract}

Keywords: Learning Inductive, Student Activities

\begin{abstract}
Abstrak : Penerapan Model Pembelajaran Induktif Untuk Meningkatkan Aktivitas Belajar PKn Siswa Di Kelas VI SD Negeri No. 050674 Bingai T.A 2015/2016. Penelitian ini bertujuan untuk meningkatkan aktivitas belajar siswa dengan menggunakan model pembelajaran Induktif di kelas VI SD Negeri No. 050674 Bingai. Subjek penelitian ini berjumlah 23 orang siswa. Penelitian berlangsung selama dua siklus dapat disimpulkan bahwa 1) Aktivitas belajar siswa melalui penerapan model pembelajaran Induktif berdasarkan pengamatan kedua pengamat mengalami peningkatan dari siklus I ke siklus II. 2) Hasil belajar siswa melalui penerapan model pembelajaran Induktif meningkat dari siklus I ke siklus II.
\end{abstract}

Kata Kunci: Pembelajaran Induktif, Aktivitas Siswa

\section{PENDAHULUAN}

Masalah utama dalam pembelajaran Pendidikan Kewarganegaraan (PKn) ialah belum tepatnya penggunaan metode atau model pembelajaran dalam menyampaikan materi pelajaran, yang memenuhi muatan tatanan nilai, agar dapat diinternalisasikan pada diri siswa serta mengimplementasikan hakekat pendidikan nilai dalam kehidupan mereka sehari-hari. Hal ini berkaitan dengan kritik masyarakat terhadap materi pelajaran PKn yang tidak bermuatan nilai-nilai praktis tetapi hanya bersifat politis atau alat indoktrinasi untuk kepentingan kekuasaan pemerintah. Strategi pembelajaran dalam Proses Belajar
Mengajar (PBM) terkesan sangat kaku, kurang fleksibel, kurang demokratis, dan guru cenderung lebih dominan (one way method). Di samping masih menggunakan model konvensional yang monoton, aktivitas guru lebih dominan daripada siswa, akibatnya guru seringkali mengabaikan proses pembinaan tatanan nilai, sikap, dan tindakan, sehingga mata pelajaran PKn tidak dianggap sebagai mata pelajaran pembinaan warga negara yang menekankan pada kesadaran akan hak dan kewajiban tetapi lebih cenderung menjadi mata pelajaran yang jenuh dan membosankan.

Berdasarkan pengalaman peneliti/ guru sampai sekarang masalah yang dihadapi dalam mengajarkan mata 
pelajaran $\mathrm{PKn}$ adalah kurangnya minat belajar, siswa, kuarang tepatnya metode pembelajaran yang digunakan yakni metode ceramah sehingga mengakibatkan siswa sering ribut di dalam kelas dan mengantuk.

Untuk meminimalkan permasalahan tersebut maka guru harus menggunakan model pembelajaran yang bertumpu pada proses membangun informasi melalui proses berpikir secara induktif. Salah satu model pembelajaran yang paling tepat yaitu model pembelajaran induktif.

Model pembelajaran induktif didasarkan pada paham empiris yang dipelopori oleh Francis Bacon dan John Locke (Suluh, 2007), berpendapat bahwa pertimbangan manusia (human judgment) merupakan kunci untuk mentransformasikan data mentah menjadi pengetahuan. Pengetahuan dibangun melalui proses induktif dari pengalaman. Data empirik yang diperoleh melalui pengindraan mengenai dunia, adalan cara terpenting untuk memperoleh kebenaran atau pengetahuan.

Berdasarkan latar belakang di atas, maka yang menjadi rumusan masalah dalam penelitian ini adalah; 1) Bagaimanakah aktivitas belajar siswa pada materi pokok ASEAN dan negaranegara di Asia Tenggara di kelas VI SD No. 050674 Bingai T.P 2015/2016 penerapan model pembelajaran induktif?; 2) Bagaimana hasil belajar siswa pada materi pokok ASEAN dan negara-negara di Asia Tenggara di kelas VI SD No. 050674 Bingai T.P 2015/2016 penerapan model pembelajaran induktif?;

Berdasarkan rumusan masalah di atas, maka tujuan penelitian ini adalah untuk; 1) Untuk mengetahui aktivitas belajar siswa pada materi pokok
ASEAN dan negara-negara di Asia Tenggara di kelas VI SD No. 050674 Bingai T.P 2015/2016 penerapan model pembelajaran induktif.; 2) Untuk mengetahui hasil belajar siswa pada materi pokok ASEAN dan negaranegara di Asia Tenggara di kelas VI SD No. 050674 Bingai T.P 2015/2016 penerapan model pembelajaran induktif; Pada hakikatnya, belajar ialah suatu proses usaha yang dilakukan sesorang untuk memperoleh suatu perubahan tingkah laku yang baru secara keseluruhan, sebagai hasil pengalamannya sendiri dalam interaksi dengan lingkungannya (Slameto, 2003: 2). Menurut Mc.Mahon dalam Trianto (2009: 16) belajar bukanlah semata-mata mentransfer pengetahuan yang ada di luar dirinya, tetapi belajar lebih pada bagaimana otak memproses dan menginterpretasikan pengalaman yang baru dengan pengetahuan yang sudah dimilikinya dalam format yang baru dimana proses pembangunan ini bisa melalui asimilasi atau akomodasi. Menurut Oemar Hamalik (2008) hasil belajar adalah bila seseorang telah belajar akan terjadi perubahan tingkah laku pada orang tersebut, misalnya dari tidak tahu menjadi tahu, dan dari tidak mengerti menjadi mengerti.

\section{METODE}

Penelitian ini dilakukan di SD No. 050674 Bingai T.P 2015/2016 dan pelaksanaannya pada bulan Februari sampai dengan Juni 2016.

Subjek dalam penelitian ini adalah seluruh siswa kelas VI SD Negeri No. 050674 Bingai dengan jumlah siswa yang terikut dalam penelitian ini sebanyak 23 orang.

Alat pengumpul data dalam penelitian ini adalah: tes hasil belajar 
untuk mengetahui kemampuan kognitif siswa dan lembar aktivitas siswa.

Penelitian ini berbentuk Penelitian Tindakan Kelas (PTK). PTK pertama kali diperkenalkanoleh psikologi sosial Amerika yang bernama Kurt Lewin pada tahun 1946 (Aqib, 2006 :13). Menurut Lewin dalam Aqib (2006 : 21) menyatakan bahwa dalam satu Siklus terdiri atas empat langkah, yaitu perencanaan (planning), tindakan (acting), observasi (observing) dan refleksi (reflecting).

Metode analisis data pada penelitian ini digunakan metode deskriptif dengan membandingkan hasil belajar siswa sebelum tindakan dengan hasil belajar siswa setelah tindakan.

Langkah-langkah pengolahan data sebagai berikut:

1) Merekapitulasi nilai pretes sebelum tindakan dan nilai tes akhir siklus I dan siklus II.

2) Menghitung nilai rata-rata atau persentase hasil belajar siswa sebelum dilakukan tindakan dengan hasil belajar setelah dilakukan tindakan pada siklus I dan siklus II untuk mengetahui adanya peningkatan hasil belajar.

Yang menjadi indikator keberhasilan guru mengajar digunakan KKM mata pelajaran PKn di SD Negeri No. 050674 Bingai dengan nilai $\geq 75$ maka disebut tuntas individu, dan bila ada $85 \%$ nilai $\geq 75$ disebut tuntas kelas.

\section{PEMBAHASAN}

SD Negeri No. 050674 Bingai Kabupaten Langkat II menggunakan Kurikulum yang diterapkan di SD Negeri No. 050674 Bingai adalah Kurikulum Tingkat Satuan Pendidikan (KTSP). Kurikulum Tingkat Satuan Pendidikan (KTSP) merupakan sebuah kurikulum yang dibuat oleh sekolah yang melibatkan unsur kepala sekolah, pembantu kepala sekolah, guru, narasumber, dan komite sekolah.

Hasil belajar dalam penelitian ini meliputi aspek kognitif, ringkasan hasil belajar kognitif siswa sebelum dan sesudah diterapkan model pembelajaran induktif sebagaimana seperti berikut ini.

Ditempuhnya tiga tahapan tersebut, diharapkan proses pembelajaran dapat menghasilkan proses belajar yang lebih baik dan siswa lebih menyeluruh dalam mendalami materi yang disampaikan oleh guru.disajikan pada Tabel.

Tabel Distribusi Hasil Pretes

\begin{tabular}{|c|c|c|}
\hline Nilai & Frekunsi & Rata-rata \\
\hline 10 & 1 & \multirow{5}{*}{27.8} \\
\hline 20 & 4 & \\
\hline 30 & 17 & \\
\hline 40 & 1 & \\
\hline Jumlah & 23 & \\
\hline
\end{tabular}

Merujuk pada Tabel, nilai terendah untuk pretes adalah 10 dan tertinggi adalah 40 dengan KKM sebesar 75 Tidak ada satu pun yang lulus KKM. Nilai rata-rata kelas adalah 27,8 dengan standar deviasi 6,0.

Hasil Postes I disajikan dalam Tabel berikut:

Tabel Distribusi Hasil Postes I

\begin{tabular}{|c|c|c|}
\hline Nilai & Frekuensi & Rata-rata \\
\hline 60 & 14 & \multirow{2}{*}{68.7} \\
\cline { 1 - 2 } 80 & 8 & \multirow{2}{*}{6} \\
\cline { 1 - 2 } 100 & 1 & \\
\cline { 1 - 2 } Jumlah & 23 & \\
\hline
\end{tabular}

Merujuk pada Tabel tersebut, nilai terendah formatif I adalah 60 dan tertinggi adalah 100 dengan 9 orang mendapat nilai di bawah kriteria ketuntasan atau ketuntasan klasikal adalah sebesar $39 \%$. Nilai ini berada di 
bawah kriteria keberhasilan sehingga dapat dikatakan KBM siklus I belum berhasil memberi ketuntasan belajar dalam kelas. Nilai rata-rata kelas adalah 68.7.

Tabel skor aktivitas belajar diperoleh dari lembar observasi aktivitas. Pengamatan dilakukan oleh dua pengamat selama 40 menit kerja kelompok dalam setiap KBM atau 80 menit dalam satu siklus. Dengan pengamatan setiap 2 menit, maka nilai maksimum yang mungkin teramati untuk satu kategori aktivitas selama 80 menit adalah 40 kali.

Tabel Skor Aktivitas Belajar Siswa

\begin{tabular}{|c|c|c|c|}
\hline \multicolumn{4}{|c|}{ Siklus I } \\
\hline No & Aktivitas & Skor & Proporsi \\
\hline 1 & $\begin{array}{l}\text { Menulis, } \\
\text { membaca }\end{array}$ & 22.5 & $37.50 \%$ \\
\hline 2 & Mengerjakan & 20.25 & $33.75 \%$ \\
\hline 3 & $\begin{array}{l}\text { Bertanya pada } \\
\text { teman }\end{array}$ & 5.25 & $8.75 \%$ \\
\hline 4 & $\begin{array}{l}\text { Bertanya pada } \\
\text { guru }\end{array}$ & 4 & $6.67 \%$ \\
\hline 5 & $\begin{array}{ll}\text { Yang } & \text { tidak } \\
\text { relevan } & \end{array}$ & 8 & $13.33 \%$ \\
\hline & Jumlah & 60 & $100 \%$ \\
\hline
\end{tabular}

Berdasarkan pada tabel pada siklus I rata-rata aktivitas I yakni menulis dan membaca memperoleh proporsi $37.50 \%$. Aktivitas mengerjakan dalam diskusi mencapai $33.75 \%$. Aktivitas bertanya pada teman sebesar $8.75 \%$. Aktivitas bertanya kepada guru $6.67 \%$ dan aktivitas yang tidak relevan dengan KBM sebesar $13.33 \%$. Nilainilai ini memperlihatkan beberapa hal diantaranya, ketika siswa berdiskusi dalam kelompok banyak kelompok yang terlihat bingung dalam pelaksanaannya sehingga peneliti kewalahan melayani pembimbingan tiap kelompok. Sementara beberapa siswa tidak aktif dalam melaksanakan diskusi, siswa tersebut hanya berdiam diri, seolah-olah tidak mau tahu dan hanya melakukan kegiatan menulis dan membaca, meskipun ada beberapa siswa yang aktif dalam berargumen. Dengan kata lain, dari seluruh komponen aktivitas belajar tersebut belum ada satu komponen aktivitas siswa yang nilainya tinggi (belum ada yang mencapai 60\%).

Setelah berakhirnya siklus II, guru memberikan tes yang merupakan Postes II. Hasil Formatif II disajikan dalam Tabel berikut:

Table Distribusi Hasil Postes II

\begin{tabular}{|c|c|c|}
\hline Nilai & Frekuensi & Rata-rata \\
\hline 60 & 3 & \multirow{2}{*}{85.2} \\
\cline { 1 - 2 } 80 & 11 & \\
\hline 100 & 9 & \\
\cline { 1 - 2 } Jumlah & 23 & \\
\hline
\end{tabular}

Merujuk pada Tabel, nilai terendah untuk formatif II adalah 60 dan tertinggi adalah 100 dengan 3 orang mendapat nilai di bawah kriteria ketuntasan atau ketuntasan klasikal adalah sebesar $87 \%$. Nilai rata-rata kelas adalah 86.9.

Skor aktivitas belajar diperoleh dari lembar observasi aktivitas. Pengamatan dilakukan oleh dua pengamat selama 40 menit kerja kelompok dalam setiap KBM atau 80 menit dalam satu siklus. Dengan pengamatan setiap 2 menit, maka nilai maksimum yang mungkin teramati untuk satu kategori aktivitas selama 80 menit adalah 40 kali.

Adapun data aktivitas yang diperoleh selama 80 menit pada siklus II adalah sebagai berikut: 
Tabel Skor Aktivitas Belajar Siswa

Siklus II

Siklus II

\begin{tabular}{|c|c|c|c|}
\hline \multicolumn{4}{|c|}{ Siklus II } \\
\hline No & Aktivitas & Skor & Proporsi \\
\hline 1 & $\begin{array}{l}\text { Menulis, } \\
\text { membaca }\end{array}$ & 16.25 & $31.71 \%$ \\
\hline 2 & Mengerjakan & 20.75 & $40.49 \%$ \\
\hline 3 & $\begin{array}{l}\text { Bertanya } \\
\text { pada teman }\end{array}$ & 8 & $15.61 \%$ \\
\hline 4 & $\begin{array}{l}\text { Bertanya } \\
\text { pada guru }\end{array}$ & 4 & $7.80 \%$ \\
\hline 5 & $\begin{array}{l}\text { Yang tidak } \\
\text { relevan }\end{array}$ & 2.25 & $4.39 \%$ \\
\hline & Jumlah & 51.25 & $100 \%$ \\
\hline
\end{tabular}

Penerapan model pembelajaran induktif pada pembelajaran PKN siklus II telah dapat meningkatkan hasil belajar siswa. Hasil belajar pada siklus II ratarata 85,2 nilai terendah 60 dan nilai tertinggi 100. Ketuntasan kelas telah melampaui batas minimal $>85 \%$ yaitu sebesar 86,95\%. Dengan demikian, hasil ini dapat dianggap bahwa pembelajaran dengan model pembelajaran induktif telah dapat meningkatkan hasil belajar siswa. Beberapa catatan perbaikan selama proses pembelajaran diketahui :

1. Dalam pelaksanaan proses pembelajaran siswa sudah mulai aktif

2. Siswa mulai membiasakan diri bertanya baik pada teman ataupun pada guru

3. Peneliti memberi perhatian lebih pada siswa yang sebelumnya dianggap kurang disiplin selama proses belajar

Dapat dilihat bahwa nilai ratarata sebelum penerapan model pembelajaran induktif pada mata pelajaran PKn yaitu berupa nilai pretes adalah 27,8 dengan ketuntasan belajar yang dicapai $0 \%$, setelah penerapan model pembelajaran induktif nilai siswa mengalami peningkatan. Berdasarkan hasil tes pada siklus I, nilai rata-rata hasil belajar yang dicapai siswa adalah 68,7 dengan persentasi $39,13 \%$, untuk nilai rata-rata hasil belajar dan persentasi ketuntasan klasikal yang dicapai belum mencapai indikator keberhasilan yang ditetapkan.

Merujuk pada tabel yang sama, hasil tes pada siklus II menunjukkan nilai rata-rata hasil belajar yang dicapai siswa adalah 85,2 dengan persentasi mencapai yaitu $86,95 \%$. Hasil belajar tersebut sudah mencapai indikator yang ditetapkan yaitu sekurang-kurangnya $85 \%$ hasil belajar siswa sudah mencapai nilai minimal 75 .

Secara keseluruhan hasil belajar siswa mengalami peningkatan dari pra pembelajaran, siklus I sampai akhir siklus II. Namun, hasil pembelajaran diakhir siklus I masih ada 14 orang siswa memperoleh nilai di bawah ketuntasan. Hal ini terjadi karena disebabkan beberapa faktor diantaranya adalah sebagai berikut.

a. Beberapa siswa belum memahami peran dan tugasnya dalam bekerja kelompok karena belum terbiasa dengan model pembelajaran yang diterapkan.

b. Interaksi antar siswa belum berjalan dengan baik karena siswa belum terbiasa untuk menyampaikan pendapatnya kepada sesama teman lainnya dalam menyelesaikan masalah.

c. Adanya siswa yang pasif dan menggantungkan permasalahan yang dihadapi kepada kelompoknya.

Uraian di atas menyatakan bahwa pada siklus I meski sebagian indikator keberhasilan telah tercapai namun terdapat 14 siswa belum tuntas nilainya. Oleh karena itu, perlu adanya suatu tindakan pada siklus II agar hasil 
belajar siswa dapat ditingkatkan dan mencapai indikator keberhasilan dengan ketuntasan klasikal mencapai maksimum. Tindakan yang diberikan berupa Pembimbingan pada masingmasing kelompok dibatasi oleh waktu yang telah ditetapkan merata untuk semua kelompok, guru menganalisis kembali kemampuan penerapan model dan materi ajar dengan memperkirakan kesulitan-kesulitan yang akan dihadapi siswa dan jalan keluar langsung yang dapat ditempuh ditengah KBM berlangsung Hasil belajar siswa diakhir siklus II telah mencapai ketuntasan klasikal 86,95\% yang berarti seluruh siswa telah memperoleh nilai tuntas. Dengan demikian tindakan yang diberikan pada siklus II telah berhasil memberikan perbaikan hasil belajar pada siswa. Hal ini dipengaruhi beberapa faktor diantaranya adalah sebagai berikut:

a. Siswa telah terbiasa dengan bekerja secara kelompok.

b. Keberanian siswa untuk berinteraksi berjalan dengan baik karena siswa sudah mulai terbiasa untuk bertanya dan menyampaikan pendapatnya kepada sesama teman lainnya dalam menyelesaikan masalah.

c. Siswa mulai aktif dan tahu akan tugasnya sehingga tidak menggantungkan permasalahan yang dihadapi kepada teman dalam kelompoknya.

\section{KESIMPULAN}

Adapun kesimpulan dari upaya meningkatkan hasil belajar siswa dan melalui model pembelajaran induktif pada mata pelajaran PKn di kelas VI SD Negeri No. 050674 Bingai sebagai berikut :
1. Hasil belajar siswa dengan menerapkan model pembelajaran induktif pada siklus I dan siklus II menunjukkan secara individu tuntas sebanyak 9 orang siswa, dan 20 orang siswa. Dengan nilai rata-rata siswa untuk formatif I dan formatif II adalah 68,7 dan 85,2. Peningkatan dan ketuntasan hasil belajar terjadi karena guru menerapkan model induktif sehingga siswa mampu untuk menyelesaikan masalah dalam mengerjakan LKS saat berdiskusi dalam kelompok.

2. Data aktivitas siswa menurut pengamatan pengamat pada siklus I antara lain: membaca/membaca (37,50\%), bekerja $(33,75 \%)$, bertanya sesama teman $(8,75 \%)$, bertanya kepada guru $(6,67 \%)$, dan yang tidak relevan dengan KBM (13,33\%). Data aktivitas siswa menurut pengamatan pada Siklus II antara lain: membaca/membaca (31,71\%), bekerja $(40,49 \%)$, bertanya sesama teman $(15,61 \%)$, bertanya kepada guru $(7,80 \%)$, dan yang tidak relevan dengan KBM (4,39\%). Peningkatan ini dikarenakan guru menerapkan model pembelajaran induktif sehingga siswa mampu untuk menyelesaikan masalah dalam mengerjakan LKS saat berdiskusi dalam kelompok.

\section{DAFTAR RUJUKAN}

Arikunto, S. (2002). Dasar-Dasar Evaluasi Pendidikan. Bumi Aksara. Jakarta. 
Aqib, Zainal. (2006). Penelitian

Tindakan Kelas. Yrama

Widya. Bandung.

Eridawati. 2016. Efektifitas Model Pembelajaran Langsung untuk Meningkatkan Aktivitas

Belajar Siswa Kelas V Pada

Mata Pelajaran PKn SD

Negeri No. 057752 T.A

2015/2016. (PTK Karangan

Sendiri).

Ibrahim, M., dkk. (2000). Pembelajaran kooperatif. Universitas Negeri Surabaya. Surabaya.

Lie, A. (2004). Cooperatif Learning Memperaktekkan Cooperatif Learning di Ruang-Ruang Kelas. PT Grasindo. Jakarta.

Syah, M. (2003). Psikologi Pendidikan. Rajagrafindo persada. Jakarta. 